Jurnal Indonesia Sosial Teknologi: p-ISSN: 2723 - 6609

e-ISSN : 2745-5254

Vol. 1, No. 5 Desember 2020

\title{
EVALUASI ATAS PERLAKUAN AKUNTANSI YANG BERKAITAN DENGAN ASSET TAK BERWUJUD PT. PLN (PERSERO) AREA CEMPAKA PUTIH
}

\section{Mustikasari}

Akademi Akuntansi Jayabaya Jakarta

Email: sripadisks@gmail.com

\section{Abstrac}

The realization of good financial reports (good governance) as an objective to determine the types of intangible assets that exist in publicly traded companies in Indonesia, treatment of intangible assets in publicly traded companies in Indonesia case study at PT. PLN (Persero) and accounting treatment in accordance with PSAK No. 19 (Revised 2015). The research method used by direct observation at PT. PLN (Persero) and sampling taken on twenty go public companies listed on the Indonesia Stock Exchange. The results showed that the intangible assets studied consisted of goodwill, $R \& D$, and other intangible assets. The accounting treatment in each company is in accordance with generally accepted standards, such as PSAK No. 19 for intangible assets and PSAK No. 48 for impairment of assets, but in the financial statements some companies classify intangible assets as other noncurrent assets.

Keywords : Accounting system treatment with PSAK.

\begin{abstract}
Abstrak
Tujuan Penelitian ini adalah terwujudnya laporan keuangan yang baik (Good Governance) sebagai tujuan untuk mengetahui jenis-jenis aset tak berwujud yang ada pada perusahaan public di Indonesia, perlakuan aset tak berwujud pada perusahaan public di Indonesia studi kasus pada PT. PLN (Persero) dan perlakuan akuntansi yang sesuai dengan PSAK No. 19 (Revisi 2015). Metode penelitian yang digunakan dengan observasi langsung pada PT. PLN (Persero) dan sampling yang diambil pada dua puluh perusahaan public yang terdaftar di Bursa Efek Indonesia. Hasil penelitian menunjukkan aset tak berwujud yang diteliti terdiri dari goodwiil, R\&D, dan aset tak berwujud lainnya. Perlakuan akuntansi di setiap perusahaan telah sesuai dengan standar-standar yang berlaku umum, seperti PSAK No.19 untuk aset tak berwujud dan PSAK No. 48 untuk penurunan nilai aset, tetapi pada laporan keuangan sebagian perusahaan mengklasifikasian aset tak berwujud pada aset tidak lancar lain.
\end{abstract}

Kata Kunci: Perlakuan sistem, akuntansi, dengan standar PSAK.

\section{Pendahuluan}

Latar belakang penelitian ini adalah untuk menentukan bahwa suatu aset atau aset merupakan sumber ekonomi, dan diharapkan aset atau aset tersebut memberikan manfaat komersial bagi perusahaan di masa yang akan datang. Aset meliputi aset lancar 
dan aset tetap. Aset likuid mengacu pada jenis aset yang dapat digunakan dalam jangka pendek (biasanya kurang dari setahun) (Wibowo \& Wartini, 2012). Pada saat yang sama, aset tetap mengacu pada aset perusahaan yang digunakan dalam waktu yang lama (lebih dari satu periode akuntansi) (Borroek, 2017). Aset tetap ini biasanya digunakan untuk memproduksi atau menyediakan barang atau jasa, disewakan kepada pihak lain atau digunakan untuk tujuan manajemen. Aktiva tetap biasanya memiliki umur yang panjang dan umur pemakaian yang panjang, sehingga diharapkan dapat memberikan banyak keuntungan bagi perusahaan (Gunawan \& Wahyuni, 2014).

Penggolongan aset tetap meliputi dua bagian : aset tetap berwujud dan aset tetap tidak berwujud (Kolinug, Ilat, \& Pinatik, 2015). Aset tetap berwujud adalah aset yang dapat dilihat dari bentuk fisiknya yang sifatnya relatif permanen dan dapat digunakan dalam waktu yang relatif lama dalam kegiatan perusahaan, seperti tanah, gedung, kendaraan, dll (Wahyuningrum, 2016). Sementara itu, aset tetap tidak berwujud mengacu pada aset yang tidak terlihat dalam bentuk fisiknya tetapi dapat membawa manfaat atau nilai ekonomis bagi perusahaan di masa depan, misalnya: hak paten, hak cipta, dan goodwill.

Dalam perekonomian dunia saat ini, nilai pasar suatu perusahaan terutama ditentukan oleh aset tidak berwujud (Abadiah, Hidayati, \& Mawardi, 2017). Perkembangan aktivitas merger dan akuisisi biasanya menghasilkan produksi aset tidak berwujud lainnya dalam laporan keuangan perusahaan. Karakteristik aset tidak berwujud adalah ketidakpastian nilai masa depannya. Dalam kebanyakan kasus, nilai aset tidak berwujud dapat berkisar dari nol hingga sangat besar (Almara \& Muharam, 2015). Beberapa aset tidak berwujud terkait dengan pengembangan dan proses produksi komoditas, dan beberapa terkait dengan penciptaan dan pemeliharaan permintaan komoditas. Perlakuan akuntansi atas aset tidak berwujud melibatkan prinsip dan prosedur akuntansi serupa yang berlaku untuk aset tidak berwujud lainnya, seperti pembelian dengan menggunakan prinsip biaya, penggunaan prinsip pencocokan, dan prinsip pelepasan pendapatan (Hasanah \& Fauzi, 2017).

Asset tetap tak berwujud dapat diperoleh dari internal maupun eksternal perusahaan, yaitu diperoleh dengan cara membeli dari pihak luar (eksternal), contohnya hak paten yang timbul dari pemerintah dan pembayaran yang mencakup goodwill dari perusahaan lain (Novianti, 2012). Asset tetap tak berwujud yang dikembangkan sendiri oleh perusahaan (internal), contohnya francise dan lease.

Apabila aset tidak berwujud diperoleh dari pihak eksternal, selain harga beli yang termasuk dalam biaya perolehan, terdapat pula biaya perolehan aset tidak berwujud, seperti biaya yang dibayarkan kepada pemerintah dan notaris, serta biaya administrasi terkait (SUWITOWATI, n.d.) . Jika aset tidak berwujud diperoleh melalui pengembangan sendiri, maka biaya tersebut meliputi biaya bahan, peralatan dan fasilitas, biaya gaji dan upah, dan biaya tidak langsung (seperti alokasi biaya administrasi dan umum). Apabila asset tak berwujud diperoleh dari pertukaran saham, maka cost dapat di anggap merupakan fair value dari saham yang diberikan atau fair value dari asset tak berwujud yang di peroleh (Maulida, 2016).

Cara lain untuk memperoleh aset tidak berwujud adalah dengan tidak memantau pertukaran aset atau sekelompok pemantau aset, atau kombinasi keduanya. Aset yang diperoleh tidak diukur pada nilai wajar Aset yang diperoleh adalah aset tidak berwujud yang diukur pada nilai buku (dilepas) (Panggabean, 2013).

Pengukuran aset tetap tidak berwujud setelah konfirmasi menggunakan model biaya revaluasi sebagai kebijakan akuntansi (Djafar, 2018). Dalam biaya, aset tidak 
berwujud setelah pengakuan awal harus dicatat sebesar biaya perolehan dikurangi akumulasi amortisasi dan akumulasi kerugian penurunan nilai. Dalam model revaluasi, setelah pengakuan awal, aset tidak berwujud harus dibuat dengan jumlah yang dievaluasi kembali, yang ditentukan oleh nilai wajar pada hari revaluasi dikurangi akumulasi amortisasi dan akumulasi kerugian penurunan nilai selanjutnya (Prihadi, 2019).

Nilai aset tidak berwujud pada akhirnya akan kedaluwarsa dalam jangka waktu tertentu, sehingga biaya harus diamortisasi secara sistematis selama taksiran masa manfaatnya. Aset tidak berwujud dengan masa manfaat terbatas harus disusutkan. Metode amortisasi aset tetap tidak berwujud adalah metode garis lurus, kecuali jika perusahaan mengadopsi metode lain yang lebih sesuai dengan kondisi perusahaan. Laporan keuangan harus mengungkapkan metode amortisasi dan jangka waktu aset tetap tidak berwujud yang digunakan (Diantimala, 2008). Pada saat yang sama, aset tidak berwujud dengan umur layanan tidak pasti tidak berarti bahwa umur layanan tidak pasti, dan perusahaan tidak akan mengamortisasi aset tetap tidak berwujud.. Perusahaan perlu melakukan pengujian penurunan nilai tahunan untuk menentukan apakah nilai terpulihkan dari aset tidak berwujud lebih rendah dari atau lebih tinggi dari nilai bukunya (Soraya \& SYAFRUDDIN, 2013).

Suatu asset tak berrwujud harus dihentikan pengakuannya bila dalam proses pelepasan atau ketika tidak terdapat lagi manfaat ekonomis masa depan yang diharapkan dari penggunaan atau pelepasannya. Keuntungan dan kerugian yang timbul dari penghentian pengakuan aset tidak berwujud dihitung berdasarkan selisih antara nilai buku aset tidak berwujud dan nilai wajar imbalan yang diterimanya.

Dalam laporan keuangan, aset tak berwujud termasuk dalam aset tak lancar. Dalam laporan laba rugi komprehensif, penyajian beban amortisasi dan kerugian dari penurunan nilai sebagai bagian dari laba operasi berkelanjutan, kecuali apabila kerugian dari penurunan nilai tersebut berhubungan dengan operasi tidak berkelanjutan.

Banyaknya perbedaan perlakuan akuntansi terhadap asset tak berwujud dalam perolehan, pengukuran setelah masa pengakuan dan amortisasi.

Tujuan penelitian ini adalah mengetahui bagaimana perlakuan akuntansi yang berkaitan dengan asset tak berwujud. Penerapannya dalam beberapa sampel perusahaan public di Indonesia maupun internasional dan studi kasus pada PT. PLN

Acuan apa yang digunakan beberapa perusahaan tersebut dalam praktik asset tetap tak berwujud Apakah mengacu pada PSAK, IFRS, IAS, dll.

\section{Metodologi Penelitian}

Metode yang digunakan dalam penelitian ini adalah metode analisis yaitu dengan menggabungkan dua metode yaitu metode studi kepustakaan dan studi kasus.

1. Studi Kepustakaan

Studi pustakaan merupakan bagian dari tahapan eksplorasi dalam metode pengumpulan data yaitu mencari informasi yang berkaitan dengan dokumen, buku atau sumber data tertulis lainnya dalam bentuk teoritis, sedangkan laporan penelitian sebelumnya terkait dengan aset tak berwujud. Digunakan sebagai data terkait penelitian dan bahan referensi, serta dapat memberikan landasan teori untuk penyusunan skripsi ini.

2. Metode Interview

Metode pengumpulan data digunakan untuk memperoleh informasi secara langsung dengan mengajukan pertanyaan lisan kepada perusahaan-perusahaan di bagian 
keuangan (terutama bagian aset tetap yang mengelola seluruh aset tetap berwujud dan tidak berwujud). Gunakan metode ini untuk mendapatkan penjelasan rinci tentang perlakuan akuntansi aset takberwujud mulai dari konfirmasi PT hingga penghapusan pada. PT. PLN (Persero) Area Cempaka Putih.

Data yang diperoleh melalui pengamatan langsung ke perusahaan maupun diperoleh dari kepustakaan dilakukan analisa oleh penulis dengan menggunakan metode sebagai berikut :

a. Metode Kuantitatif.

Seluruh data aset tak berwujud yang bersifat kuantitatif yaitu berbentuk angka yang akan dianalisis oleh penulis dengan menggunakan perhitungan, sehingga data tersebut dapat membantu dalam pengambilan suatu kesimpulan mengenai ketetapan perhitungan maupun unsure-unsur perhitungannya.

b. Metode Kualitatif.

Seluruh data aset tak berwujud yang diperoleh tidak dalam bentuk angka akan dianalisis dengan membandingkan antara perlakuan akuntansi aset tak berwujud menurut Pernyataan Standar Akuntansi (PSAK) dengan praktek-praktek yang berjalan diperusahaan baik dari segi perlakuan akuntansi atas perolehan, masa manfaat maupun penghapusan aset tak berwujud.

\section{Hasil dan Pembahasan}

Akuntansi aset tidak berwujud merupakan masalah penting di tahun 1980-an dan tetap menjadi topik kontroversial di tahun 1990-an. Untuk mempromosikan pemahaman kerangka diskusi teoritis tentang aset tidak berwujud, yang terbaik adalah membagi jenis aset tidak berwujud ini menjadi tiga bagian. :

a. Goodwill

b. Research and Development (R \& D) / (Penelitian dan Pengembangan)

c. Asset tidak berwujud lainnya seperti brands, trademarks, patent, organization cost dan sejenisnya.

\section{Pendekatan Kerangka Konseptual (The Conceptual Framework Approach)}

Penjelasan tentang tujuan dan konsep yang mendasari laporan keuangan atau kerangka konseptual mungkin berguna dan memberikan dasar untuk metode akuntansi alternatif untuk mengevaluasi aset tidak berwujud. Kesimpulan dari International Accounting Standards Committee (IASC) dalam rangka penyusunan dan penyajian laporan keuangan (1989) Berdasarkan konsep tersebut, orang setuju bahwa tujuan laporan keuangan adalah untuk memberikan informasi yang berguna kepada banyak pengguna untuk keperluan pengambilan keputusan dan menjadi Tanggung jawab manajemen. Sumber daya diserahkan kepada mereka. Oleh karena itu, informasi tersebut harus mengandung unsur-unsur yang "relevan dan dapat diandalkan" (relevan dan dapat diandalkan). Selain itu, informasi yang diberikan juga harus memberikan nilai yang "dapat dibandingkan" dan "dapat dimengerti" (dapat dibandingkan dan dapat dipahami). Konsep penting dalam pelaporan aset adalah pengakuan.

\section{Kesimpulan}

Jenis asset tak berwujud yang ada pada perusahaan di Indonesia dengan sampel dua puluh perusahaan go public terdiri dari; goodwill, $R \& D$, dan asset tak berwujud lainnya. 
Perlakuan akuntansi asset tak berwujud di kebanyakan perusahaan go public di Indonesia dari sampel yang diambil, sebagian mengacu pada PSAK yang berlaku umum, seperti penurunan nilai asset sesuai dengan PSAK 48, perlakuan akuntansi asset tak berwujud sesuai PSAK 19, pengakuan dan pengukuran instrument keuangan sesuai dengan PSAK 55. Namun dibeberapa perusahaan sampel menggunakan PSAK 16 yang merupakan standar akuntansi untuk asset tetap berwujud, termasuk PT. PLN (Persero). Dari keseluruhan sampel yang diteliti, perbedaan yang signifikan terletak pada pengklasifikasian asset dalam laporan keuangan konsolidasian, dimana sebagian 
Evaluasi Atas Perlakuan Akuntansi Yang Berkaitan Dengan Asset Tak Berwujud PT. PLN (Persero) Area Cempaka Putih

\section{Bibliografi}

Abadiah, Tsamrotul Masrifatil, Hidayati, Nur, \& Mawardi, M. Cholid. (2017). ANALISIS PENGARUH ASET TIDAK BERWUJUD DAN KINERJA KEUANGAN TERHADAP NILAI PERUSAHAAN (STUDI EMPIRIS TERHADAP PERUSAHAAN MANUFAKTUR YANG TERDAFTAR DI BEI TAHUN 2013-2015). Jurnal Ilmiah Riset Akuntansi, 6(04).

Almara, Dheni Saraswati, \& Muharam, Harjum. (2015). Analisis Pengaruh Nilai Sukuk, Rating Sukuk, dan Risiko Sukuk terhadap Last Yield Sukuk (Studi Kasus Perusahaan Konvensional non-bank yang Menerbitkan Sukuk di Indonesia Periode tahun 2008-2011). Fakultas Ekonomika dan Bisnis.

Borroek, Maria Rosario. (2017). Perancangan Sistem Informasi Manajemen Aset pada STIKOM Dinamika Bangsa Jambi (Studi Kasus: Penjualan dan Disposal Aset Tetap). Jurnal Ilmiah Media SISFO, 8(2), 61-74.

Diantimala, Yossi. (2008). pengaruh akuntansi konservatif, ukuran perusahaan, dan default risk terhadap koefisien respon laba (ERC). Jurnal Telaah Dan Riset Akuntansi, 1(1), 102-122.

Djafar, Juliana Sartika. (2018). AKUNTANSI ASET TETAP KENDARAAN BERDASARKAN PSAK 16 Tahun 2015 (Studi Kasus pada PT. XYZ).

Gunawan, Ade, \& Wahyuni, Sri Fitri. (2014). Pengaruh rasio keuangan terhadap pertumbuhan laba pada perusahaan perdagangan di Indonesia. Jurnal Ilmiah Manajemen Dan Bisnis, 13(1).

Hasanah, Nuramalia, \& Fauzi, Achmad. (2017). Akuntansi pemerintahan. Bogor: In Media.

Kolinug, Monika Sutri, Ilat, Ventje Ilat, \& Pinatik, Sherly. (2015). Analisis Pengelolaan Aset Tetap pada Dinas Pendapatan Pengelolaan Keuangan dan Aset Daerah Kota Tomohon. Jurnal EMBA: Jurnal Riset Ekonomi, Manajemen, Bisnis Dan Akuntansi, 3(1).

Maulida, Alfiatul. (2016). PENGARUH KURS DAN SUKU BUNGA SBI SERTA INFLASI MELALUI RETURN ON ASSET TERHADAP RETURN SAHAM.

Novianti, Ita. (2012). TINJAUAN ATAS METODE PENYUSUTAN ASET TETAP PADA PERUSAHAAN DAERAH AIR MINUM (PDAM) KOTA BANDUNG. Universitas Widyatama.

Panggabean, Rosinta Ria. (2013). Isu Penyatuan Akuntansi Atas Aset Tak Berwujud. Binus Business Review, 4(2), 821-833.

Prihadi, Toto. (2019). Analisis Laporan Keuangan. Gramedia Pustaka Utama. 
Mustikasari

Soraya, Letsa, \& SYAFRUDDIN, Muchammad. (2013). Pengaruh Nilai Aset Tidak Berwujud dan Penelitian dan Pengembangan Terhadap Nilai Pasar Perusahaan (Studi Empiris pada Perusahaan Manufaktur yang Terdaftar di Bursa Efek Indonesia Tahun 2009-2010). Fakultas Ekonomika dan Bisnis.

SUWITOWATI, NIKEN A. Y. U. (n.d.). Penerapan Standar Akuntansi Pemerintahan (SAP) tentang Aset Tetap pada Dinas Penanaman Modal dan Pelayanan Terpadu Satu Pintu Kabupaten Jember.

Wahyuningrum, Sekar. (2016). Pengaruh Ukuran Perusahaan, Total Aset, dan Jumlah Pekerja Terhadap Klasifikasi Perusahaan Manufaktur Di Indonesia Dengan Metode Regresi Logistik Biner. Universitas Negeri Semarang.

Wibowo, Agus, \& Wartini, Sri. (2012). Efisiensi Modal Kerja, Likuiditas dan Leverage terhadap Profitabilitas pada Perusahaan Manufaktur di BEI. JDM (Jurnal Dinamika Manajemen), 3(1). 